\title{
Drying and reduction in sensitivity to desiccation of seeds of Alibertia edulis: the influence of fruit ripening stage
}

\author{
THAIS CREMON, DAIANE M. DRESCH, SILVANA P.Q. SCALON* and TATHIANA E. MASETTO \\ Faculdade de Ciências Agrárias/FCA, Universidade Federal da Grande Dourados/UFGD, Rodovia \\ Dourados, Itahum, Km 12, Cidade Universitária, 79804-970 Dourados, MS, Brazil
}

Manuscript received on August 24, 2017; accepted for publication on November 8, 2017

\begin{abstract}
The intense environmental degradation in tropical regions suitable for agriculture has decreased native forest populations of plants with important fruits and medicinal properties. Alibertia edulis is a native tree from the Brazilian Cerrado. Knowledge about the effects of drying and storage on the physiological behavior of its seeds may aid in its sustainable exploitation and conservation. The goal of the present study was to determine which fruit ripening stage results in A. edulis seeds with higher tolerance to desiccation, and to investigate the effectiveness of polyethylene glycol (PEG) induced osmotic stress in combination with abscisic acid (ABA) in increasing seed desiccation tolerance during storage. Seeds were dried in activated silica gel (fast) or under ambient conditions (slow). Seeds originating from mid-ripe or fully ripe fruits exhibited better physiological performance than those obtained from green fruits. Slow drying resulted in seeds with high physiological potential. Seeds may be stored for up to 180 days without losing viability when treated with $-0.73 \mathrm{MPa}$ PEG without ABA.
\end{abstract}

Key words: fast drying, slow drying, polyethylene glycol, abscisic acid, storage.

\section{INTRODUCTION}

The Brazilian Cerrado occupies approximately $22 \%$ of the national territory, includes the sources of the three largest hydrographic basins in South America, and is acknowledged as the savanna with the highest biodiversity in the world (MMA 2016). Its soil and relief characteristics make Cerrado a successful agroecosystem, which has contributed to the acceleration of its degradation (Pires and Moreno 2014). In addition, when

Correspondence to: Daiane Mugnol Dresch

E-mail: daiamugnol@hotmail.com

* Bolsista / CNPq compared to other Brazilian biomes, such as the Amazon, Cerrado has been neglected in terms of policies for its conservation and the sustainable use of its biodiversity, contributing to its increasing fragmentation (Ganem et al. 2013).

Knowledge about the physiological characteristics of native plant species of the Cerrado is essential for the adequate management, and therefore the preservation of this biome. Fruits of several species are consumed by local populations and have high potential for use, including export, because of their characteristic colors and flavors and high nutritional value (Pereira and Pasqualeto 2011). 
Alibertia edulis (Rich.) A. Rich. ex DC., commonly known as puruí, puruizinho, marmeladade-cavalo, apuruí, goiaba-preta, and marmelo-decachorro, is a semi-deciduous plant, occurring from the Amazon region to the Central Brazilian Cerrado. Its fruits have fleshy and sweet pulp, and are highly valued by the local population. Its flowering season is from October to December, and its fruits ripen from December to February (Lorenzi 2002). Although it is economically important, there is little information about its sustainable management. Knowledge of the ideal season to harvest fruits of A. edulis for seed propagation could increase the collection of seeds with more uniform germination, and consequently higher seedling production.

Because fruits from many forest species change color when they ripen, changes in fruit color have been widely used as the indicator of seed maturity for the harvest of forest seeds (Srimathi et al. 2013, Lopes et al. 2014, Kaiser et al. 2016). In addition to fruit color, other factors such as seed water content and ambient temperature during storage are essential to the maintenance of physiological viability and genetic conservation of plant species, and these factors are frequently the subject of $e x$ situ conservation studies on forest seeds (Borges et al. 2009). According to Hay and Probert (2013), the stage of maturity is also of practical importance during collection of seeds of non-cultivated species for seed banking. It is often necessary to harvest seeds before they are fully ripe as this will secure collection prior to dispersal. However, this practice also leads to the collection of a significant proportion of immature seeds that are unsuitable for long-term storage.

Seeds of A. edulis are classified as intermediate because they do not survive drying to $10 \%$ water content, or storage for more than 60 days under freezing temperatures, making the maintenance of seed viability in germplasm banks difficult (Bento et al. 2016). However, osmotic treatment with polyethylene glycol (PEG) and abscisic acid
(ABA) has been observed to efficiently decrease seed metabolism and induce or increase desiccation tolerance in both recalcitrant and orthodox seeds (Faria et al. 2005, Maia et al. 2014, Masetto et al. 2015), and may increase seed desiccation tolerance in A. edulis.

The goal of the present study was to (1) determine the best fruit ripening stage to obtain $A$. edulis seeds capable of tolerating fast (in activated silica gel) and slow drying (ambient laboratory conditions), and (2) determine the effectiveness of PEG and ABA treatment in increasing seed desiccation tolerance during storage.

\section{MATERIALS AND METHODS}

Fruits of A. edulis were collected from Cerrado areas within the Santa Madalena Farm $\left(22^{\circ} 08^{\prime} \mathrm{S}\right.$, $55^{\circ} 08^{\prime} \mathrm{W}$ ), located on highway BR $270, \mathrm{Km} 45$, which connects the municipalities of Dourados and Itahum, in the State of Mato Grosso do Sul (MS). After collection, the fruits were taken to the Laboratory of Plant Nutrition and Metabolism of the Federal University of Grande Dourados (Universidade Federal da Grande Dourados UFGD), in Dourados, MS, where they were processed.

\section{EXPERIMENT 1: FRUIT RIPENING STAGE AND SEED DRYING}

Fruits of $A$. edulis were collected at different ripening stages, based on epicarp color, and classified as follows: 1) green fruits: hard pulp and light-colored seeds (Fig. 1a); 2) mid-ripe fruits: collected green, but underwent post-harvest ripening for 15 days, and had soft pulp and a dark brown color (Fig. 1b); and 3) fully ripe fruits: dark brown color, soft pulp, and dark seeds (Fig. 1c). The fruits were then placed on sieves under water and manually processed to separate the seeds from fruit pulp. Seeds originating from fruits from the three different ripening stages were then washed, 
placed on paper towels for $40 \mathrm{~min}$ at ambient temperature $\left(25 \pm 2^{\circ} \mathrm{C}, 35 \%\right.$ relative humidity, $\left.\mathrm{RH}\right)$, and subjected to two types of drying: fast drying, in activated silica gel, and slow drying, under ambient laboratory conditions.

For fast drying, seeds were placed on a steel screen inside lidded "gerbox" plastic boxes containing silica-gel ( $8 \% \mathrm{RH})$ on the bottom; the silica gel was periodically changed when the surface layer lost its indicative blue color. For slow drying, seeds were placed in uncovered plastic containers, at $25 \pm 2{ }^{\circ} \mathrm{C}$ and $35 \% \mathrm{RH}$. The seeds were weighed every hour until they reached the following pre-defined water contents: $40,30,20$, 15,10 and $5 \%$, as determined by the equation of Sacandé et al. (2004). The seeds were then prehumidified in a humid chamber $\left(25^{\circ} \mathrm{C}, 100 \% \mathrm{RH}\right.$, and under constant white light) for $24 \mathrm{~h}$ to prevent possible imbibition damage, and subjected to the tests and examinations described below.

Water content: was determined at $105^{\circ} \mathrm{C} \pm 3^{\circ} \mathrm{C}$ for $24 \mathrm{~h}$ using the oven method (Brasil 2009) with three replicates of $5 \mathrm{~g}$ of seeds.

Primary root protrusion: was measured on Germitest $^{\circledR}$ paper rolls with four replications of 25 seeds each, germinated with BOD. (Biochemical Oxygen Demand) at $25^{\circ} \mathrm{C}$ under continuous white light. Assessments were conducted daily, and the root was considered protruded when it reached a length of $5 \mathrm{~mm}$. The results were expressed in percentages $(\%)$.

Percentage of normal seedlings: was determined in Germitest ${ }^{\circledR}$ paper rolls with four replications of 25 seeds each, which were germinated with $\mathrm{BOD}$ at $25^{\circ} \mathrm{C}$ under continuous white light. Evaluations were performed $45 \mathrm{~d}$ after sowing by calculating the percentages of normal seedlings, using the presence of shoots and root system development as the criteria. The results were expressed in percentages (\%).

Seedling length: was obtained by measuring the lengths of the shoot and primary root, with four replications of 10 seedlings each using a millimeter ruler. The results were expressed in centimeters $(\mathrm{cm})$.

Total dry mass: was obtained from four replications of 10 seedlings that had been dried in an oven at $60^{\circ} \mathrm{C}$ for $48 \mathrm{~h}$ using an analytical balance $(0.0001 \mathrm{~g})$, with the results expressed in grams $(\mathrm{g})$.

The experiment was assembled on a completely randomized experimental design in a factorial scheme 3 fruit colors (green, medium and mature) x 2 drying methods (fast and slow) x 6 water levels $(40,30,20,15,10$ and 5\%). The data were subjected to analysis of variance and regression analysis was performed to $5 \%$ probability with statistical software SISVAR ${ }^{\circledR}$.

\section{EXPERIMENT 2: INCREASE IN DESICCATION TOLERANCE}

To evaluate the effectiveness of PEG and ABA in increasing desiccation tolerance during seed storage, seeds originating from fully ripe fruits (dark brown color and soft pulp) were washed and placed on paper towels to remove excess moisture, under ambient laboratory conditions (25 $\left.\pm 1{ }^{\circ} \mathrm{C}, 35 \% \mathrm{RH}\right)$. Immature and broken seeds were discarded, and visually uniform whole seeds were selected.

Seeds were divided into two samples, one of which was used for the control treatment (without PEG-induced osmotic stress or ABA treatment). The second sample was soaked in -0.73 or -1.48 MPa PEG (6000) solution, alone or together with $100 \mu \mathrm{M} \mathrm{ABA}$, and placed in a B.O.D. chamber at $25^{\circ} \mathrm{C}$ for $120 \mathrm{~h}$. Following osmotic conditioning, the seeds were washed in running water for five min to remove the osmotic solution, and surfacedried on paper towels. The seeds were then subjected to fast drying in activated silica gel $(8 \%$ $\mathrm{RH})$, and weighed every hour until they reached the following water contents the $10 \%$, as determined by the equation by Sacandé et al. (2004): 


$$
P f=P i \cdot\left(\frac{100-T A i}{100-T A f}\right)
$$

In which Pf is the final mass of the sample (g); $\mathrm{Pi}$ is the initial mass of the sample (g); TAI is the initial water content of achenes (\% w.b.); TAf is the level of desiccation (\% w.b.). Water content was also determined using the oven method $\left(105 \pm 3^{\circ} \mathrm{C}\right.$ for $24 \mathrm{~h}$ ) (Brasil 2009).

After reaching the desired water content, seeds were placed in aluminum package $(10 \mathrm{~cm} \times 10$ $\mathrm{cm} \times 1.5 \mathrm{~cm})$ and stored in a cold chamber $(16 \pm$ $2^{\circ} \mathrm{C}, 40 \% \mathrm{RH}$ ) for $0,30,60,90,120,150$, or 180 days. Following each period, seeds were removed from storage, and pre-humidified at $25^{\circ} \mathrm{C}$ and $100 \% \mathrm{RH}$ for $24 \mathrm{~h}$ to prevent imbibition damage. Seed physiological potential was evaluated by performing tests and examinations described for experiment 1.

A completely randomized experimental design was used, with a $3 \times 2 \times 7$ factorial scheme (PEG concentration $\times$ ABA treatment $\times$ storage time), with four replicates of 25 seeds. The data were subjected to an analysis of variance (ANOVA), averages of qualitative factors were compared using the Tukey test, and averages of quantitative factors were analyzed using regression analysis. Significance was set at $p \leq 0.05$, and analyses were performed using SISVAR software.

\section{RESULTS}

\section{EXPERIMENT 1}

Seeds originating from green, mid-ripe, and ripe fruits took less time to reach 5\% water content when subjected to fast drying (silica gel; 20, 22, and $28 \mathrm{~h}$, respectively) than to slow drying (ambient; $22 \mathrm{~h}$ for green and mid-ripe fruits, and $36 \mathrm{~h}$ for ripe fruits) (Fig. 1).

Significant single effects were observed for fruit ripening stage and seed water content on primary root protrusion (Fig. 2a, b) and shoot length

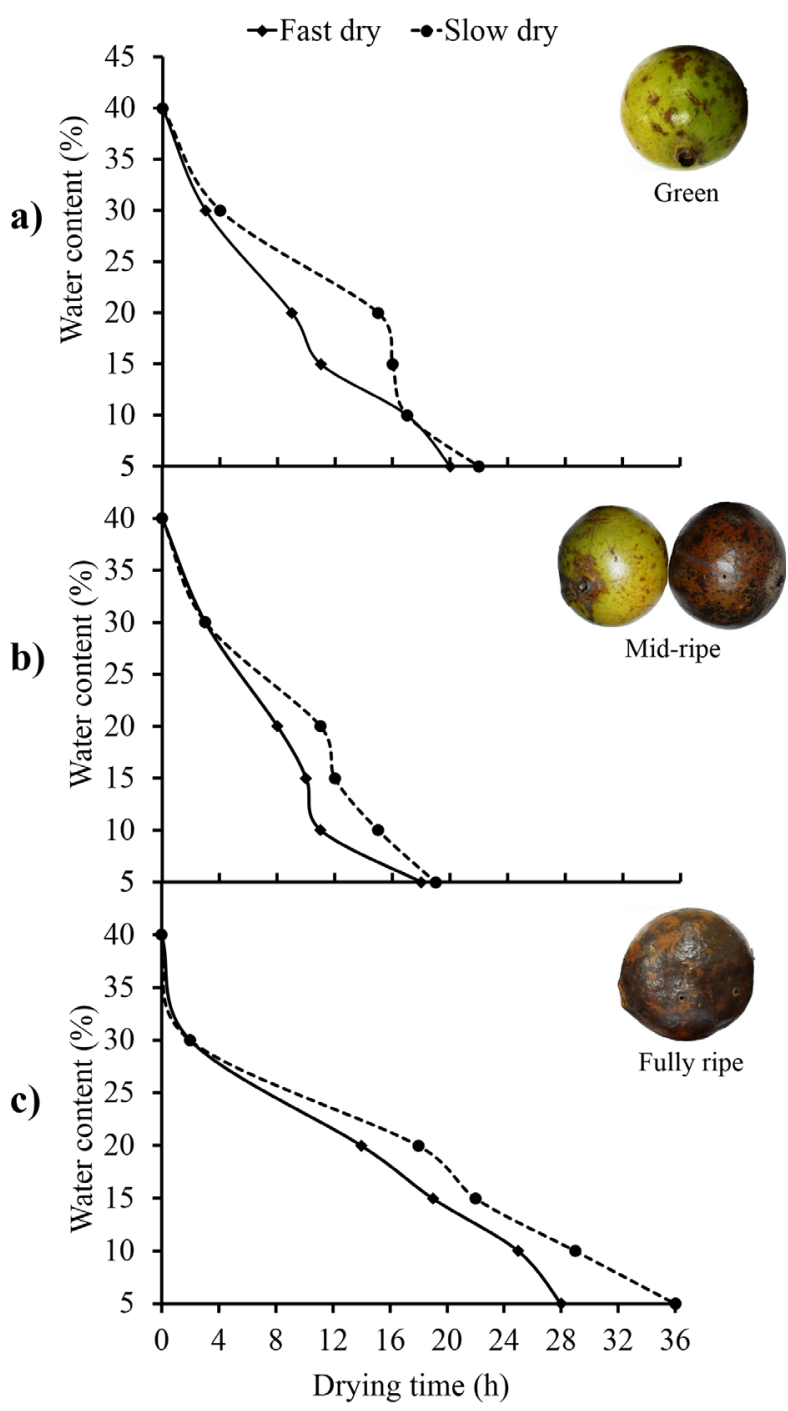

Figure 1 - Drying rate of Alibertia edulis seeds: fast drying (silica gel) and slow drying (room temperature) from fruit in various stages of ripening (a - green, $\mathbf{b}$ - mid-ripe and c- fully ripe).

(Fig. 2d, e), and for fruit ripening stage on seed germination (Fig. 2c). Primary root protrusion was higher for seeds originating from mid-ripe fruits (83\%) (Fig. 2a), and with $28.4 \%$ water content (82.9\%) (Fig. 2b). Normal seedlings increased with fruit ripening, being $70 \%$ for seeds originating from green fruits, $75 \%$ for seeds originating from ripe fruits, and 78\% from mid-ripe fruits (Fig. 2c).

Fruit ripening stage significantly affected seedling growth, with the greatest shoot length 
a)

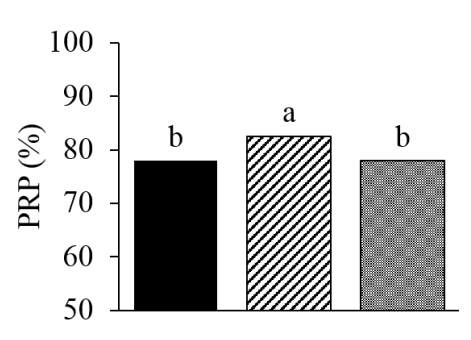

- Fully ripe $\square$ Mid-ripe G Green b)

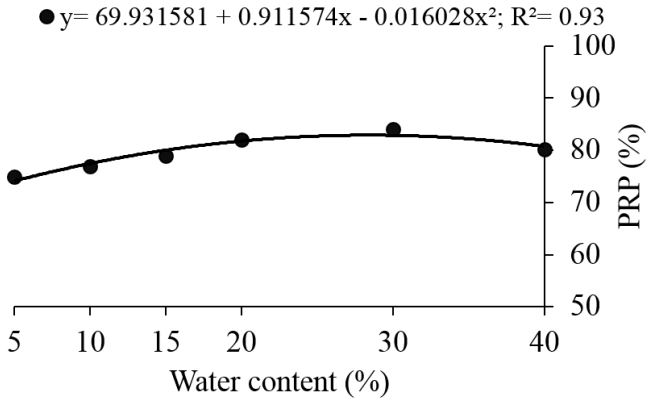

c)

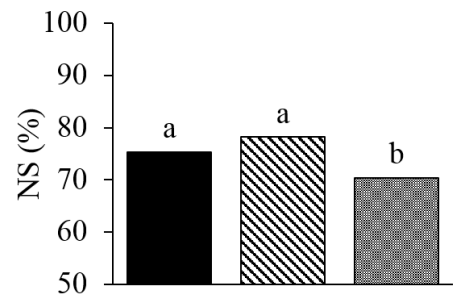

- Fully ripe $\mathbf{\text { Mid-ripe }}$ Green d)

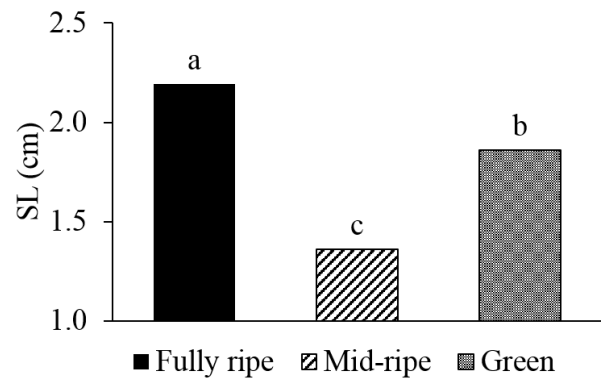

f)

-(---) Fully ripe $y=4.6088+0.1386 x-0.00290 x^{2} ; R^{2}=0.65$

-(‥) Mid-ripe $\mathrm{y}=5.1040+0.1687 \mathrm{x}-0.00411 \mathrm{x}^{2} ; \mathrm{R}^{2}=0.60$

เ(一) Green $\mathrm{y}=6.8578-0.0637 \mathrm{x} ; \mathrm{R}^{2}=0.92$

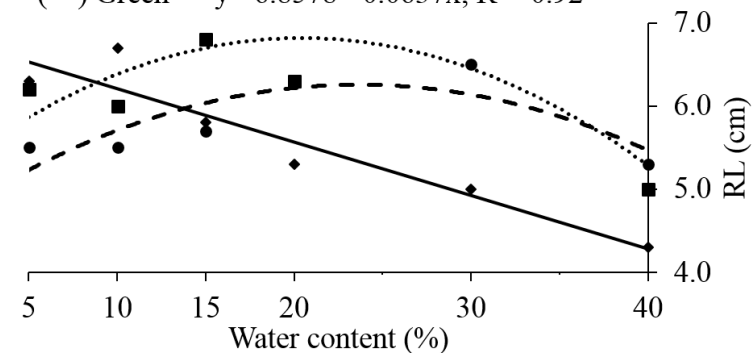

e)

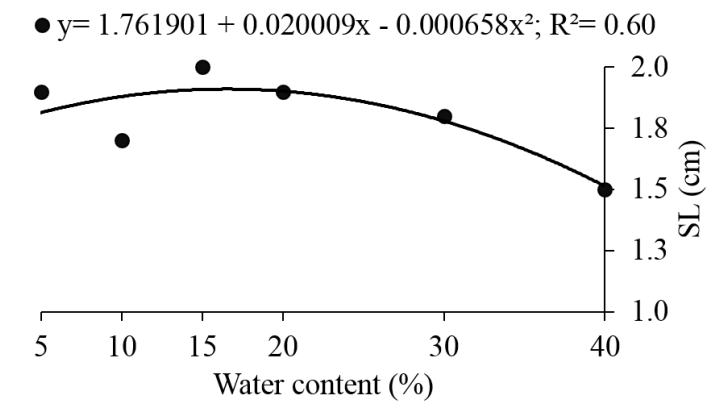

g)

- (一) Slow $\mathrm{y}=6.5381-0.0287 \mathrm{x} ; \mathrm{R}^{2}=0.46$

$+(\cdots)$ Fast $\mathrm{y}=4.8450+0.1494 \mathrm{x}-0.00376 \mathrm{x}^{2} ; \mathrm{R}^{2}=0.60$

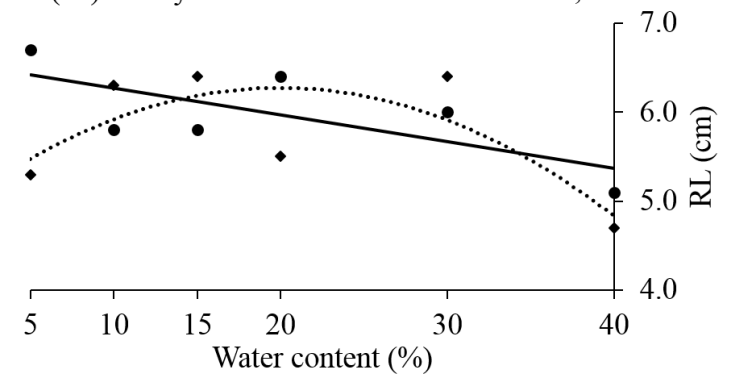

Figure 2 - Primary root protrusion - PRP \% (a, b), normal seedlings NS \% (c), shoot length (SL - cm) (d, e) and root length (RL $\mathrm{cm})(\mathbf{f}, \mathbf{g})$ of A. edulis from fruit in various stages of ripening (fully ripe, mid-ripe and green) and drying of the seeds at different water contents.

observed for seeds originating from ripe fruits $(2.2 \mathrm{~cm})$, followed by green $(1.8 \mathrm{~cm})$, and midripe fruits $(1.4 \mathrm{~cm})$ (Fig. 2d). The greatest shoot length was observed for seedlings originating from seeds with $15.2 \%$ water content $(1.91 \mathrm{~cm})$, and the lowest from seeds with $40 \%$ water content $(1.50$ $\mathrm{cm}$ ) (Fig. 2e), indicating that, independent of the drying speed, reducing the $A$. edulis seed water content to $15 \%$ had a positive effect on seed vigor, as indicated by shoot length.
Significant interactions were observed between fruit ripening stage $\times$ seed water content and drying speed $\times$ seed water content for primary root length (Fig. 2d, e, respectively). Primary root length of seedlings originating from green fruits increased linearly with decreasing seed water content, down to $5 \%(6.53 \mathrm{~cm})$. The highest primary root growth for seeds originating from ripe and mid-ripe fruits was observed for $23.8 \%(6.26 \mathrm{~cm})$ and $20.5 \%$ $(6.83 \mathrm{~cm})$ water content, respectively (Fig. 2f). For 
slow drying, primary root growth increased with decreasing seed water content down to 5\% $(6.68$ $\mathrm{cm})$, whereas for fast drying the greatest root length was observed for $19.9 \%$ water content $(6.33 \mathrm{~cm})$ (Fig. 2g). This indicates that, although decreasing the water content of $A$. edulis seeds under $10 \%$ had a negative effect on seed physiological potential, there was a relationship between seed drying speed and seed desiccation tolerance, which may be related to the degree of seed ripening.

Significant interactions were observed between fruit ripening stage $\times$ drying speed, seed water content $\times$ fruit ripening stage, and seed water content $\times$ drying speed on total dry mass seedling (Fig. 3). The highest total dry mass seedling were observed for seedlings originating from mid-ripe fruits, independent of drying speed. It should be noted that for seeds originating from green fruits, slow drying resulted in better seedling performance than fast drying (Fig. 3a). For seedlings originating from mid-ripe fruit seeds, total biomass accumulation linearly increased with decreasing water content down to $5 \%(6.2 \mathrm{~g})$. However, the lowest total biomass accumulation was observed for seedlings originating from ripe fruit seeds with $5 \%$ water content $(4.5 \mathrm{~g}$ ), and green fruit seeds with 20.5\% water content (3.6 g) (Fig. 3b). The lowest total dry biomass accumulation was observed for seeds subjected to slow drying down to $22 \%$ water content (4.6 g) (Fig. 3c).

\section{EXPERIMENT 2}

For the experiment of increased desiccation tolerance, a significant three-factor interaction was observed between PEG concentration $\times$ ABA treatment $\times$ storage time for protrusion of primary root, normal seedlings (Fig. 4), root and shoot length and total dry mass (Fig. 5). a)

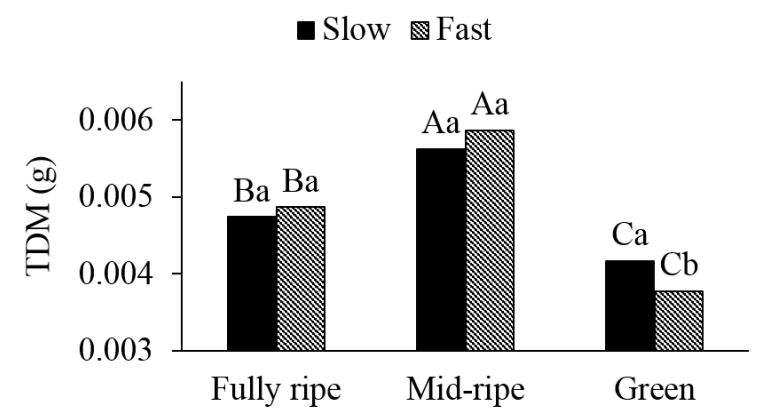

\section{b)}

- (--) Fully ripe $y=0.0044+0.00001 x ; R^{2}=0.66$

- (‥) Mid-ripe $y=0.0064-0.000033 x ; R^{2}=0.90$

- (一) Green $y=0.0045-0.00008 x+0.000002 x^{2} ; R^{2}=0.96$

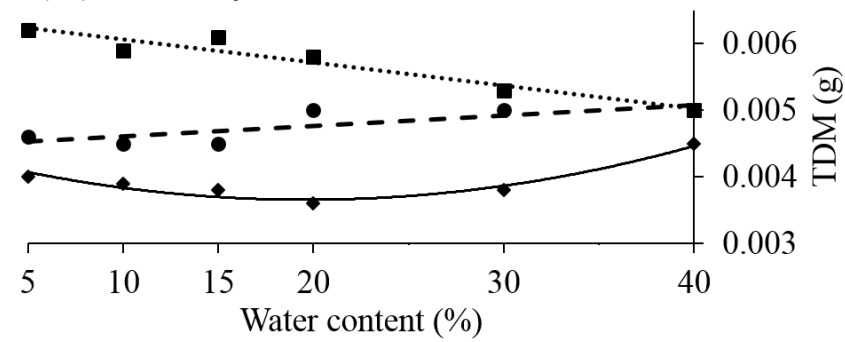

c)

$$
\text { -(一) Slow } y=0.005145-0.000044 x+0.000001 x^{2} ; R^{2}=0.46
$$

- Fast $y=$ without adjustment

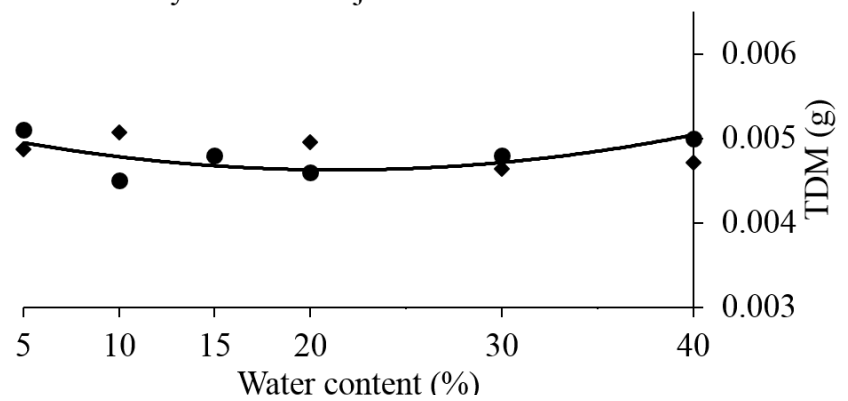

Figure 3 - Total dry mass (TDM - g) $(\mathbf{a}, \mathbf{b}, \mathbf{c})$ of seedlings of $A$. edulis from seeds harvested in fruits of different stages of ripeness of the fruit (fully ripe, mid-ripe and green), drying types (fast drying - silica and slow drying - room temperature) and water contents. 
a)

WITHOUT ABA

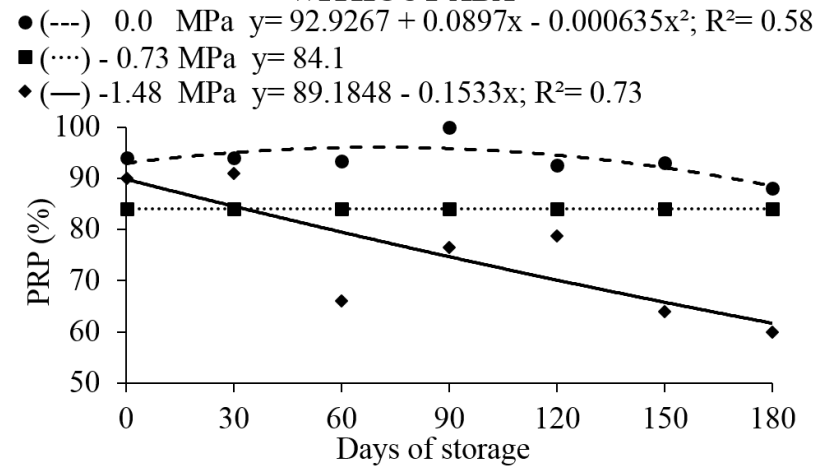

c)

WITHOUT ABA

$\bullet(--) \quad 0.0 \quad$ MPa $y=80.3011+0.1340 \mathrm{x}-0.001473 \mathrm{x}^{2} ; \mathrm{R}^{2}=0.39$

(…) $-0.73 \mathrm{MPa} y=77.9$

-(一) -1.48 MPa $y=84.5595-0.4708 x+0.000046 x^{2} ; R^{2}=0.82$

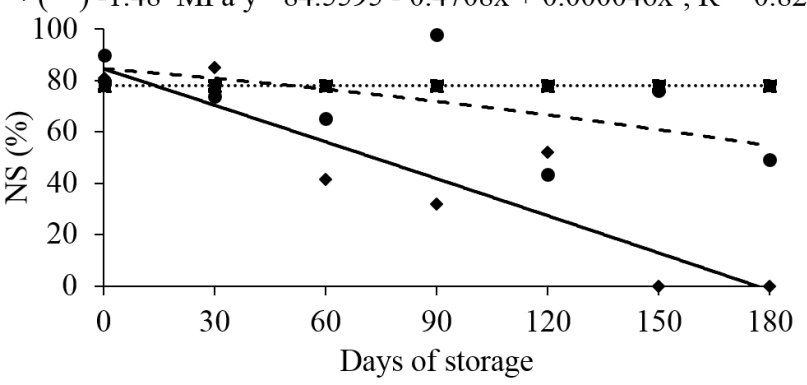

b)

WITH ABA

- (---) 0.0 MPa $\mathrm{y}=91.2738+0.1380 \mathrm{x}-0.00086 \mathrm{x}^{2} ; \mathrm{R}^{2}=0.70$

- (․) $-0.73 \mathrm{MPa} y=74.5$

-(一) -1.48 MPa $\mathrm{y}=81.8452-0.2375 \mathrm{x}-0.001144 \mathrm{x}^{2} ; \mathrm{R}^{2}=0.55$

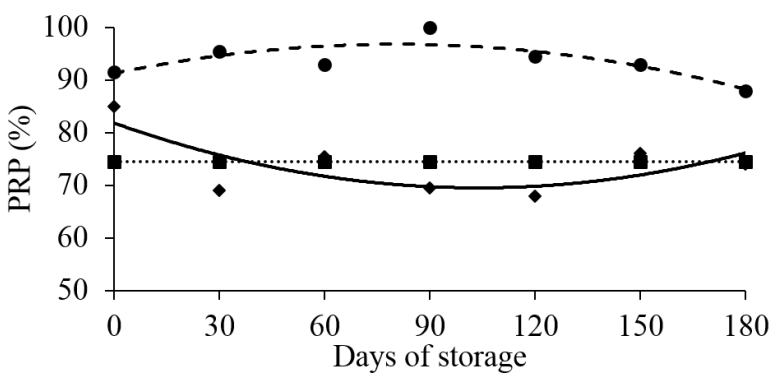

d)

WITH ABA

$\bullet(--) \quad 0.0 \mathrm{MPa} y=78.9791+0.1520 \mathrm{x}-0.001500 \mathrm{x}^{2} ; \mathrm{R}^{2}=0.30$ - (‥) - 0.73 MPa $y=62.5690+0.0979 x-0.002458 x^{2} ; R^{2}=0.79$ -(一) $-1.48 \mathrm{MPa} y=69.1547-1.0077 \mathrm{x}+0.0041 \mathrm{x}^{2} ; \mathrm{R}^{2}=0.96$

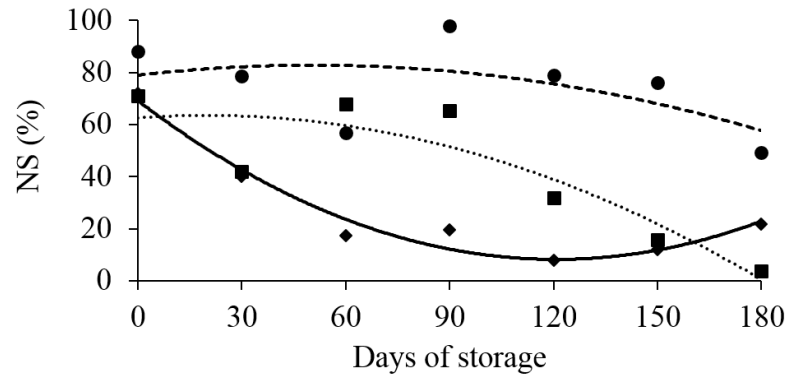

Figure 4 - Primary root protrusion - PRP \% (a, b) and normal seedlings NS \% (c, d) of A. edulis from seeds previously submitted to osmotic treatment with polyethylene glycol (PEG) in the potential of -0.73 and $-1.48 \mathrm{MPa}$, associated or not with abscisic acid (ABA) and subsequently stored for different periods.

Without PEG treatment, the highest primary root protrusion was observed after 71 days of storage without $\mathrm{ABA}$, and after 80 days with $\mathrm{ABA}$ (both 97\%) (Fig. 4a, b). The highest percentage of normal seedlings was observed after 50 days of storage, without $(83.3 \%$; Fig. $4 \mathrm{c})$ or with $\mathrm{ABA}$ (82.8\%; Fig. 4d). Seeds treated with -0.73 MPa PEG without ABA exhibited an overall average primary root protrusion of $84.1 \%$ and $77.9 \%$ of normal seedlings for 180 days of storage. The treatment with -1.48 MPa PEG without ABA negatively affected primary root protrusion (59.7\%) (Fig. 4a), and was lethal to the formation to normal seedlings after 180 days of storage (Fig. 4c).

The seeds treated with ABA and submitted at the same PEG osmotic potential showed $10 \%$ normal seedlings as the minimum result at 123 days storage (Fig. 4d), indicating the ABA exogenous promoted or induced tolerance to the stress caused by the osmotic medium. Nevertheless, the same positive effects were not observed in the seeds submitted at $-0.73 \mathrm{MPa}$ with $\mathrm{ABA}$ addition, since the maximum result was $63.5 \%$ normal seedlings after 20 days storage, towards reduction at the end of the storage period (Fig. 4d).

Without PEG treatment, shoot growth was higher after 70 days of storage without ABA treatment, and after 73 days with ABA treatment (both $2.03 \mathrm{~cm}$; Fig. 5a, b), and root growth was higher after 180 days of storage with $\mathrm{ABA}$ treatment $(5.77 \mathrm{~cm})$ and without ABA treatment at 47 days $(4.72 \mathrm{~cm})$ (Fig. 5c, d). With -0.73 MPa PEG and 
a)

WITHOUT ABA

$\bullet(--) \quad 0.0 \mathrm{MPa} y=1.6509+0.0113 \mathrm{x}-0.000080 \mathrm{x}^{2} ; \mathrm{R}^{2}=0.64$

- (‥) $-0.73 \mathrm{MPa} y=1.53$

-(一) -1.48 MPa $y=1.9179-0.010247 x ; \mathrm{R}^{2}=0.86$

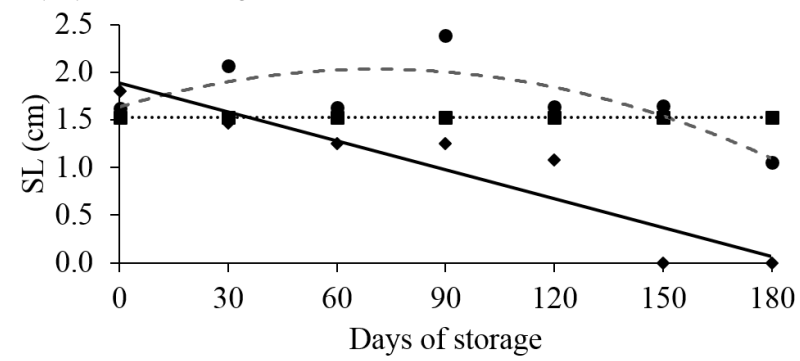

c)

\section{WITHOUT ABA}

-(--) 0.0 MPa $y=4.9005-0.0072 \mathrm{x}+0.000076 \mathrm{x}^{2} ; \mathrm{R}^{2}=0.55$

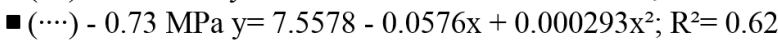

- (一) - $1.48 \mathrm{MPa} y=6.3934+0.0094 \mathrm{x}-0.000266 \mathrm{x}^{2} ; \mathrm{R}^{2}=0.80$

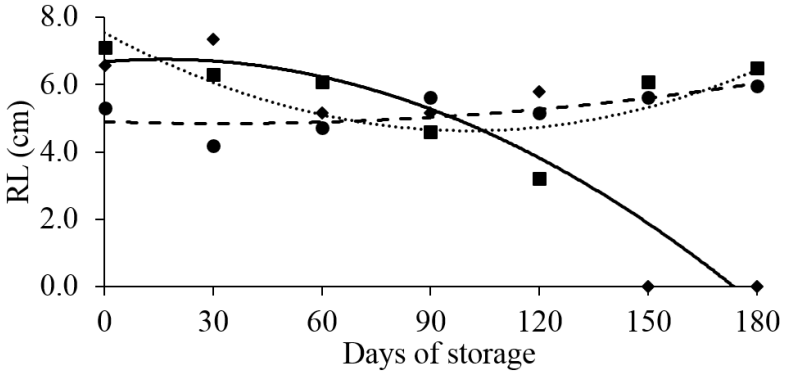

e)

WITHOUT ABA

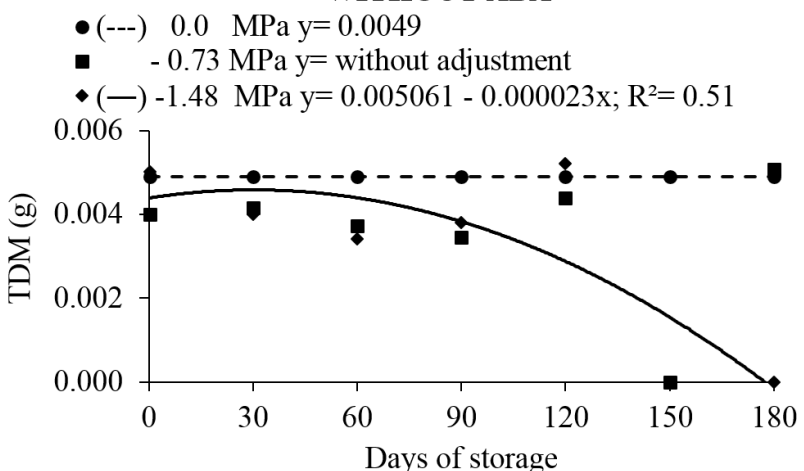

b)

WITH ABA

-(--) 0.0 MPa $y=1.5869+0.0121 \mathrm{x}-0.000083 \mathrm{x}^{2} ; \mathrm{R}^{2}=0.63$

- (‥) - 0.73 MPa $y=1.6234+0.0014 x-0.000031 x^{2} ; R^{2}=0.40$

- $($ - $)-1.48 \mathrm{MPa} y=1.5942-0.0085 \mathrm{x}+0.000028 \mathrm{x}^{2} ; \mathrm{R}^{2}=0.57$

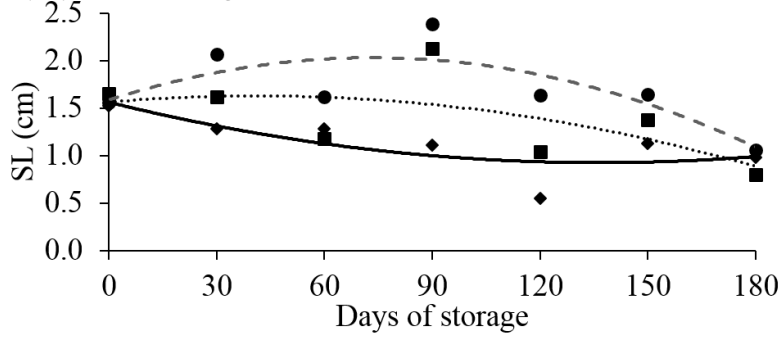

d)

WITH ABA

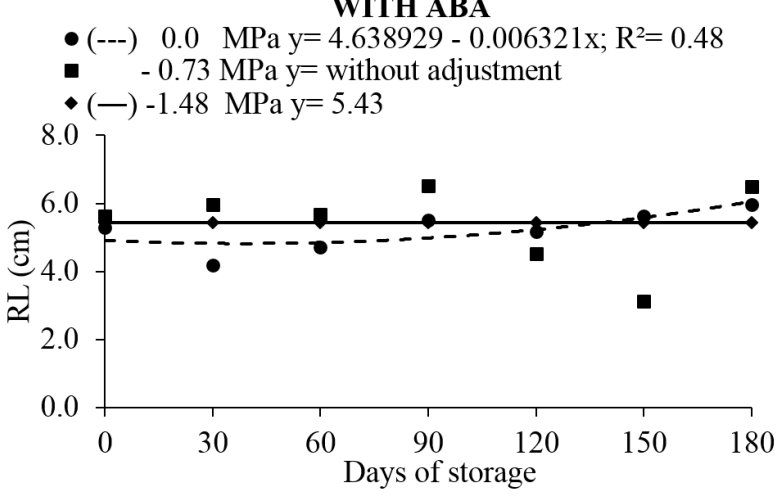

f)

\section{WITH ABA}

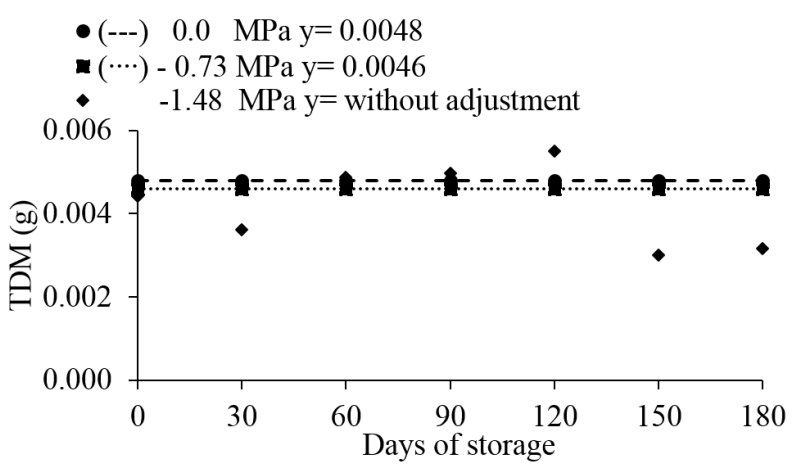

Figure 5 - Shoot length $(\mathrm{SL}-\mathrm{cm})(\mathbf{a}, \mathbf{b})$, root length $(\mathrm{RL}-\mathrm{cm})(\mathbf{c}, \mathbf{d})$ and total dry mass $(\mathrm{TDM}-\mathrm{g})(\mathbf{e}, \mathbf{f})$ of $A$. edulis from seeds previously submitted to osmotic treatment with polyethylene glycol (PEG) in the potential of -0.73 and $-1.48 \mathrm{MPa}$, associated or not with abscisic acid (ABA) and subsequently stored for different periods. 
without $\mathrm{ABA}$, the overall average shoot length was $1.53 \mathrm{~cm}$, and primary root growth was highest after 98 days of storage $(4.72 \mathrm{~cm})$.

Without PEG treatment, the average total seedling dry mass was $4.8 \mathrm{mg}$ with ABA, and 4.9 mg without ABA (Fig. 5e, f). Treatment with -1.48 MPa PEG without ABA had a negative effect on total seedling dry mass, which was lowest after 180 days of storage $(0.8 \mathrm{mg})$ (Fig. $5 \mathrm{e})$.

\section{DISCUSSION}

Seed water content decreases during seed development, being highest in its initial stages, and lowest in mature seeds. However, no significant variation in initial water content between different fruit ripening stages was observed in seeds of $A$. edulis (overall 40\% water content) (Fig. 1). It should be noted that the pulp of green fruits of $A$. edulis is more solid and rigid than that of ripe fruits with their moister pulp, which may contribute to the maintenance of high seed water content even in ripe fruits.

Although no variation in initial seed water content was observed following extraction from the fruits, seeds underwent physiological changes during fruit ripening. Seeds of $A$. edulis originating from ripe fruits exhibited higher primary root protrusion, percentage of normal seedlings and shoot growth (Fig. 2), indicating that the color of ripe fruits was related to seeds with higher germination and vigor, and that propagation may be more efficient if the seeds originated from fruits collected at the ripe stage. Similar results were observed for Allophylus edulis (A. St.-Hil., A. Juss. \& Cambess.) Hieron. ex Niederl., for which red-colored fruits had seeds with lower water content, coinciding with the highest percentage of germination and speed, and producing bigger seedlings and higher biomass accumulation (Kaiser et al. 2016). From a physiological point of view, for that seeds which are non-dormant and have orthodox behavior at time dispersal, seeds entering the late maturation phase have already gained their germination capacity and desiccation tolerance, both occurring much earlier, when seeds are being filled (Angelovici et al. 2010, Leprince et al. 2017).

However, seeds dried to $15 \%$ water content exhibited better seedling performance than moist seeds ( $40 \%$ water content), as indicated by shoot length, suggesting that artificial drying may trigger the physiological program of seedling growth (Fig. 2e), which could be related to the degree of seed maturity because seeds originating from green fruits needed a more drastic decrease in water content $(5 \%)$ than seeds from riper fruits (approximately $20 \%$ water content) (Fig. 2f). The development of germinability during seed ripening is related to different regulatory mechanisms, such as changes in soluble sugar concentration and composition (Verdier et al. 2013), decreased nuclear size and chromatin condensation (Zanten et al. 2011), and accumulation of heat shock protein (Chauhan et al. 2012) and late embryogenesis abundant protein (Dekkers et al. 2016). Conversely, seeds originating from green fruits had the lowest germination rate and seedling growth, indicating that seeds were still developing, and that their germination capacity was not fully developed.

Thus, these mechanisms the expression of defence-related components during seed maturation could be a programmed mechanism will also have an impact on the longevity of the seed. This raises the question as to whether seed longevity evolved by co-opting existing genetic pathways regulating the activation of defence against pathogens, to ensure proper protection during storage in the soil until they are ready to germinate (Leprince et al. 2017).

The different tested drying methods did not affect seed germination; however, for green fruits, fast drying had a negative effect on root growth, resulting in decreased biomass accumulation with decreasing seed water content. The positive 
results observed for slow drying may be related to sufficient time being allowed for the induction and function and/or activation of protective mechanisms (Pammenter and Berjak 1999), which would be negatively affected by rapid water removal resulting from fast drying.

Osmotic treatment with $-0.73 \mathrm{MPa}$ PEG without ABA resulted in a higher percentage of normal seedlings after 180 days of storage, and seeds that were not submitted to the osmotic treatments exhibited higher germination rates after 50 days of storage. This illustrated that PEG treatment was efficient for the maintenance of seed physiological potential, allowing a slow and gradual dehydration, and inducing protective mechanisms against seed desiccation. Previous studies suggested that the stress caused by the water deficit and decrease in cell volume during desiccation induced ABA accumulation (Taylor et al. 2000, Jia et al. 2001).

According to the results, in the presence of ABA a such tolerance behavior to the osmotic stress was observed after PEG treatment which seems to be determined through the water restriction that the seeds were exposed; at the higher osmotic potential $(-1.48 \mathrm{MPa})$ there was a tendency to resume the normal seedlings formation along the seed storage, since under the moderate osmotic stress $(-0.73$ $\mathrm{MPa}$ ), there was an increase in the percentage of normal seedlings yet 20 days storage, and tendency decrease subsequently. That result indicate the beneficial effects of ABA addition are closely associated with the intensity of the osmotic stress which $A$. edulis seeds were submitted and to the storage period.

In seeds, the efficiency of ABA treatment in seeds subjected to severe PEG stress was also observed in germinated seeds of Sesbania virgata (Cav.) Poir. with 1-3 mm radicle length (Masetto et al. 2015), since the beneficial effects of ABA were also associated with the intensity of the osmotic stress caused by PEG solutions. In this way, most of the studies have shown that ROS (Reactive Oxygen Species) production was suppressed by exogenous ABA in seeds (Ishibashi et al. 2012, Ye et al. 2012) and embryonic axis (El-MaaroufBouteau et al. 2015), that are substances related to the cell oxidative stress possibly indicating that ABA stimuli tissue tolerance against stress.

The success of ex situ seed conservation depends on knowledge about seed behavior and viability during storage. Bento et al. (2016) observed intermediate physiological behavior for seeds of $A$. edulis, because they did not tolerate storage longer than 60 days under freezing conditions $\left(-18^{\circ} \mathrm{C}\right)$. Under cold chamber conditions $\left(16^{\circ} \mathrm{C}\right)$, seeds with $10 \%$ water content had the highest percentage of normal seedlings (74.5\%) after 73 days of storage. Seed soaking in $-0.73 \mathrm{MPa}$ PEG without ABA resulted in increased seed desiccation tolerance, which enabled seed storage for up to 180 days, and resulted in the formation of $77.9 \%$ normal seedlings.

\section{CONCLUSIONS}

Seeds originating from mid-ripe or fully ripe fruits exhibited better physiological performance than seeds originating from green fruits.

Slow drying had a positive effect on the physiological quality of $A$. edulis seeds.

Seeds of $A$. edulis can be stored for up to 180 days without losing viability when treated with -0.73 MPa PEG without ABA.

\section{ACKNOWLEDGMENTS}

The authors acknowledge the Coordenação de Aperfeiçoamento de Pessoal de Nível Superior (CAPES), Programa Nacional de Pós-Doutorado (PNPD/CAPES-Projeto 2673/2011).

\section{REFERENCES}

ANGELOVICI R, GALILI G, FERNIE AR AND FAIT A. 2010. Seed desiccation: a bridge between maturation and germination. Trends Plant Sci 15(4): 211-218.

BENTO LF, DRESCH DM, SCALON SDPQ AND MASETTO TE. 2016. Storage of Alibertia edulis seeds: Influence of water content and storage conditions. Afr J Agric Res 11(18): 1646-1655. 
BORGES S, BORGES EEL, CORREA PC AND BRUNE A. 2009. Equilíbrio higroscópico e viabilidade de sementes de angico-vermelho (Anadenanthera peregrina (L.) Speng) em diferentes condições ambientais de armazenamento. Sci For 37(84): 475-481.

BRASIL. 2009. Ministério da Agricultura, Pecuária e Abastecimento. Secretaria de Defesa Agropecuária. Regras para análise de sementes. Brasília, DF: Mapa/ACS, 395 p.

CHAUHAN H, KHURANA N, NIJHAVAN A, KHURANA JP AND KHURANA P. 2012. The wheat chloroplastic small heat shock protein (sHSP26) is involved in seed maturation and germination and imparts tolerance to heat stress. Plant Cell Environ 35(11): 1912-1931.

DEKKERS BJW, HE H, HANSON J, WILLEMS LA, JAMAR DC, CUEFF G, RAJJOU L, HILHORST HW AND BENTSINK L. 2016. The Arabidopsis delay of germination 1 gene affects abscisic acid insensitive 5 (ABI5) expression and genetically interacts with ABI3 during Arabidopsis seed development. Plant J 85: 451-465.

EL-MAAROUF-BOUTEAU H, SAJJAD Y, BAZIN J, LANGLADE N, CRISTESCU SM, BALZERGUE S, BAUDOUIN E AND BAILLY C. 2015. Reactive oxygen species, abscisic acid and ethylene interact to regulate sunflower seed germination. Plant Cell Environ 38: 364374.

FARIA JMR, BUITINK J, VAN LAMMEREN AAM AND HILHORST HWM. 2005. Changes in DNA and microtubules during loss and re-establishment of desiccation tolerance in germinating Medicago truncatula seeds. J Exp Bot 56(418): 2119-2130.

GANEM RS, DRUMMOND JÁ AND FRANCO JLA. 2013. Conservation polices and control of habitat fragmentation in the brazilian cerrado biome. Amb Soc 6(3): 99-118.

HAY FR AND PROBERT RJ. 2013. Advances in seed conservation of wild plant species: a review of recent research. Conserv Physiol 1(1): $\cot 030$.

ISHIBASHI Y, TAWARATSUMIDA T, KONDO K, KASA S, SAKAMOTO M, AOKI N AND IWAYA-INOUE M. 2012. Reactive oxygen species are involved in gibberellin/ abscisic acid signaling in barley aleurone cells. Plant Physiol 158: 1705-1714.

JIA W, LIANG J AND ZHANG J. 2001. Initiation and regulation of water deficit induced abscisic acid accumulation in maize leaves and roots: cellular volume and water relations. J Exp Bot 52(355): 295-300.

KAISER DK, MALAVASI MM, MALAVASI UC, DRANSKI JAL, FREITAS LCN, KOSMANN CR AND ANDRIOLI KK. 2016. Maturidade fisiológica de sementes e colorimetria dos frutos de Allophylus edulis [(A. St.-Hil., A. Juss. \& Cambess.) Hieron. ex Niederl.]. J Seed Sci 38(2): 092-100.

LEPRINCE O, PELLIZZARO A, BERRIRI S AND BUITINK J. 2017. Late seed maturation: drying without dying, J Exp Bot 68(4): 827-841.
LOPES IS, NÓBREGA AMF AND MATOS VP. 2014. Maturação e colheita da semente de Amburana cearensis (Allem.) A.C. Smith. Ci Fl 24(3): 565-572.

LORENZI H. 2002. Árvores brasileiras: manual de identificação e cultivo de plantas arbóreas do Brasil, v. 1, $4^{\mathrm{a}}$ ed., Nova Odessa, SP: Instituto Plantarum, 384 p.

MAIA J, DEKKERS BJW, DOLLE MJ, LIGTERINK W AND HILHORST HWM. 2014. Abscisic acid (ABA) sensitivity regulates desiccation tolerance in germinated Arabidopsis seeds. New Phytol 203: 81-93.

MASETTO TE, FARIA JMR AND FRAIZ ACR. 2015. Loss and re-establishment of desiccation tolerance in the germinated seeds of Sesbania virgata (Cav.) (Pers.). Acta Sci Agr 37(3): 313-320.

MMA - MINISTÉRIO DO MEIO AMBIENTE. 2016. O bioma Cerrado. Disponível em: http://www.mma.gov.br/ biomas/cerrado. Acesso em 20 de Setembro de 2016.

PAMMENTER NW AND BERJAK PA. 1999. A review of recalcitrant seed physiology in relation to desiccationtolerance mechanisms. Seed Sci Res 9(1): 13-37.

PEREIRA ME AND PASQUALETO A. 2011. Desenvolvimento sustentável com ênfase em frutíferas do Cerrado. Estudos 38(2): 333-363.

PIRES NAMT AND MORENO MIC. 2014. A conservação da biodiversidade ao longo do processo de ocupação do Cerrado. B G Journal 5(2): 326-351.

SACANDÉ M, JOKER D, DULLOO M AND THOMSEN KA. 2004. Comparative storage biology of tropical tree seeds. Roma: International Plant Genetic Resources Institute, $363 \mathrm{p}$.

SRIMATHI P, MARIAPPAN N, SUNDARAMOORTHY L AND SUDHAKAR K. 2013. Studies on floral phenology, fruit and seed maturation and harvest index based on fruit colour in Pongamia pinnata (L.) Pierre. Afr J Agric Res 7(11): 513-520.

TAYLOR IB, BURBIDAGE A AND THOMPSON AJ. 2000. Control of abscisic acid synthesis. J Exp Bot 51(350): 1563-1574.

VERDIER J. 2013. A regulatory network-based approach dissects late maturation processes related to the acquisition of desiccation tolerance and longevity of Medicago truncatula seeds. Plant Physiol 163: 757-774.

YE N, ZHU G, LIU Y, ZHANG A, LI Y, LIU R AND ZHANG J. 2012. Ascorbic acid and reactive oxygen species are involved in the inhibition of seed germination by abscisic acid in rice seeds. J Exp Bot 63: 1809-1822.

ZANTEN VM, KOINI MA, GEYER R, LIU Y, BRAMBILLA V, BARTELS D, KOORNNEEF M, FRANSZ P AND SOPPE WJJ. 2011. Seed maturation in Arabidopsis thaliana is characterized by nuclear size reduction and increased chromatin condensation. Proc Natl Acad Sci USA 108: 20219-20224. 